\title{
Program Pemulihan Ekonomi Nasional Sebagai Kebijakan Penanggulangan Dampak Pandemi Covid-19 Pada Sektor UMKM
}

\author{
Ratnawaty Marginingsih \\ Universitas Bina Sarana Informatika \\ e-mail: ratnawaty.rmg@bsi.ac.id

\begin{tabular}{ccc}
\hline Diterima & Direvisi & Disetujui \\
$15-07-2021$ & $21-07-2021$ & $15-09-2021$ \\
\hline
\end{tabular}

\begin{abstract}
Abstrak Berbagai permasalahan yang terjadi pada UMKM terdampak pandemi cukup dirasakan oleh para pelaku usaha tersebut. Hal ini tentu saja berakibat pada penurunan keuntungan secara signifikan dikarenanakan tingkat produktivitas yang rendah. Langkah terkait pemulihan ekonomi, dalam hal ini pemerintah melalui kementrian keuangan membuat kebijakan luar biasa untuk memitigasi dampak covid-19 dan perlambatan ekonomi dengan membuat Program Pemulihan Ekonomi Nasional (PEN). Metode penelitian yang digunakan dalam penulisan ini adalah teknik analisis deskriptif kualitatif. Hasil penelitian menujukkan Program Pemulihan Ekonomi Nasional (PEN) memiliki dampak positif bagi sektor UMKM pada masa pandemi covid-19 sebagai langkah kebijakan yang diambil oleh pemerintah untuk mendukung pemulihan perekonomian nasional khususnya sektor UMKM yang memiliki kontribusi cukup besar. Rekomendasi kebijkan penguatan UMKM tidak hanya pada masa pandemi tetapi juga pada masa pemulihan dan pasca pandemi sehingga percepatan pemulihan ekonomi nasional dapat mencapai kestabilannya.
\end{abstract}

Kata Kunci: Program PEN, Kebijkan Pandemi, UMKM

\begin{abstract}
The various problems that occur in SMEs affected by the pandemic are quite felt by these business actors. This of course results in a significant reduction in profits due to low productivity levels. Steps related to economic recovery, in this case, the government through the ministry of finance, make extraordinary policies to mitigate the impact of covid-19 and the economic slowdown by creating the National Economic Recovery Program (PEN). The research method used in this paper is a qualitative descriptive analysis technique. The results of the study show that the National Economic Recovery Program (PEN) has a positive impact on the MSME sector during the COVID-19 pandemic as a policy step taken by the government to support the recovery of the national economy, especially the MSME sector which has a significant contribution. Recommendations for strengthening MSME policies are not only during the pandemic but also during the recovery and post-pandemic period so that the acceleration of national economic recovery can achieve stability.
\end{abstract}

Keywords: PEN Program, Pandemic Policy, MSME

\section{PENDAHULUAN}

Kontribusi Usaha Mikro, Kecil dan Menengah di Indonesia memiliki peran yang penting dan strategis dalam meningkatkan perekonomian. Hal ini disebabkan UMKM mampu membuat perluasan kesempatan kerja dan penyerapan tenaga kerja. Selain itu juga keberadaan UMKM menjadi bagian pembentukan Produk Domestik Brutto (PDB) serta sebagai penyediaan jaring pengaman terutama bagi masyarakat yang memiliki pendapatan rendah untuk menjalankan kegiatan ekonomi produktif .(Putri, 2019)

Terjadinya wabah Coronavirus disease 2019 yang kemudian disebut sebagai Pandemi Covid19 di akhir tahun 2019 lalu menjadi masalah dunia internasional termasuk di Indonesia. Pandemi Covid19 memberikan implikasi ekonomi, sosial, dan politik hampir di seluruh negara, termasuk di Indonesia.
Dampak ekonomi akibat pandemi Covid-19 juga dirasakan sektor UMKM yang ada di Indonesia. Data dari Bank Indonesia menyebutkan sebanyak 87,5\% UMKM terdampak pandemi covid-19. Dari jumlah ini sekitar 93,2\% diantaranya terdampak negatif di sisi penjualan .(Saputra, 2021)

Berbagai permasalahan yang terjadi pada UMKM terdampak pandemi cukup dirasakan oleh para pelaku usaha tersebut. Hal ini tentu saja berakibat pada penurunan keuntungan secara signifikan dikarenanakan tingkat produktivitas yang rendah. Secara garis besar masalah yang dihadapi oleh UMKM meliputi masalah non keuangan dan keuangan. Berikut masalah yang dihadapi oleh UMKM dapat disajikan dalam gambar dibawah ini: 


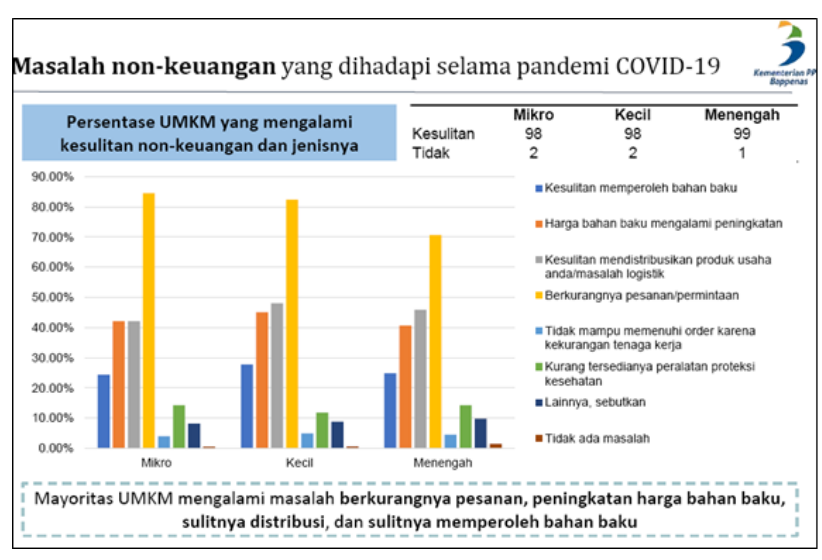

Sumber: Bappenas (2020)

Gambar 1

\section{Masalah Non Keuangan UMKM Selama Pandemi}

Berdasarkan gambar diatas dapat dilihat bahwa mayoritas UMKM mengalami masalah non keuangan meliputi berkurangnya pesanan yang memiliki persentase tertinggi hingga $80 \%$, peningkatan harga bahan baku persentase diatas 45\%, sulitnya mendistribusikan produk dengan persentase hingga mendekati $50 \%$ dan sulitnya memperoleh bahan baku persentase mendekati 30\%. (Bappenas, 2020)

Sedangkan untuk masalah keuangan dapat dilihat pada gambar berikut ini:

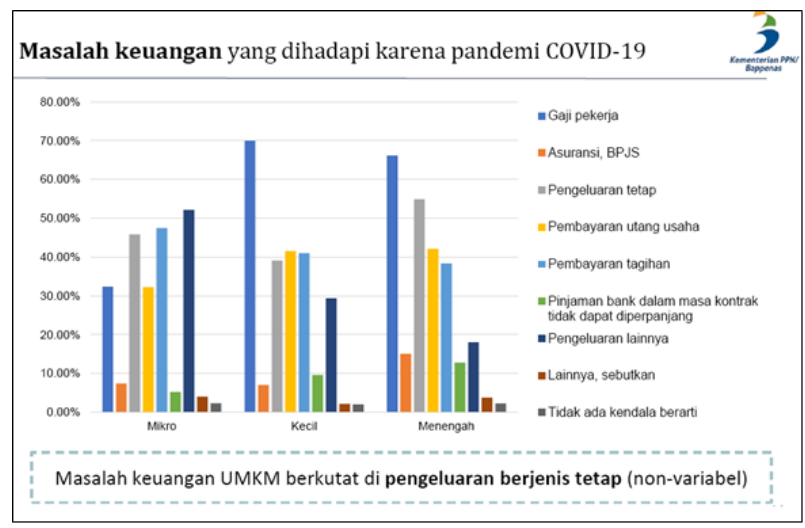

Sumber: Bappenas (2020)

Gambar 2.

Masalah Keuangan UMKM Selama Pandemi

Berdasarkan gambar diatas dapat dilihat bahwa mayoritas UMKM mengalami masalah keuangan meliputi gaji pekerja dengan persentase tertinggi mencapai $70 \%$, pembayaran utang usaha diatas $40 \%$, pengeluaran tetap berjenis non variabel sebesar 55\%, pembayaran tagihan diatas $40 \%$, pinjaman bank persentase diatas $20 \%$ dan pengeluaran lainnya hampir mencapai 30\%. (Bappenas, 2020)

Untuk membangkitkan kembali geliat usaha para pelaku UMKM diperlukan solusi mitigasi dan pemulihan. Pemerintah memberi respon terhadap pandemi ini dengan memberikan bantuan modal kerja, subsidi kredit UMKM, hingga relaksasi bunga kredit perbankan demi mempertahankan sektor
UMKM. Tidak hanya dari sisi suplainya, pemerintah juga mendorong sisi permintaan agar pengusaha UMKM terus menggeliatkan usahanya meski masih dalam pandemi (Faqir, 2021)

Langkah terkait pemulihan ekonomi, dalam hal ini pemerintah melalui kementrian keuangan membuat kebijakan luar biasa untuk memitigasi dampak covid-19 dan perlambatan ekonomi dengan membuat Program Pemulihan Ekonomi Nasional (PEN). Melalui Program Pemulihan Ekonomi Nasional (PEN) bertujuan untuk melindungi, mempertahankan, dan meningkatkan kemampuan ekonomi para pelaku usaha dalam menjalankan usaha dalam masa pandemi covid-19 serta untuk meningkatkan kinerja UMKM yang sudah berkontribusi pada perekonomian Indonesia.

\section{Usaha Mikro, Kecil dan Menengah (UMKM)}

UMKM merupakan salah satu pilar utama dalam perekonomi nasional. Menurut Rudjito dalam (Hamidah, et.al, 2019) Mengemukakan bahwa pengertian Usaha Mikro Kecil dan Menengah (UMKM) adalah usaha yang punya peranan penting dalam perekonomian Negara Indonesia, baik dari sisi lapangan kerja yang tercipta di dalamnya maupun dari sisi jumlah usahanya.

Definisi UMKM menurut (Undang-Undang No. 20 Tahun 2008) tentang Usaha Mikro, Kecil dan Menengah (UMKM) yang tertuang pada Bab 1 Pasal 1 dejelaskan bahwa Usaha mikro adalah usaha produktif milik orang perorangan dan atau badan usaha perorangan yang memenuhi kriteria usaha mikro. Selanjutnya usaha kecil adalah usaha produktif yang berdiri sendiri, yang dilakukan oleh perseorangan atau badan usaha bukan merupakan anak cabang perusahaan yang dimiliki, dikuasai, atau menjadi bagian baik secara langsung maupun tidak langsung dari usaha menengah atau besar yang memenuhi kriteria sebagai usaha kecil. Kemudian dijelaskan usaha menengah adalah usaha ekonomi produktif yang berdiri sendiri, yang dilakukan oleh orang perorangan atau badan usaha yang bukan merupakan anak perusahaan atau cabang perusahaan yang dimiliki, dikuasai, ataupun menjadi bagian baik secara langsung maupun tidak langsung dengan usaha kecil atau usaha besar dengan jumlah kekayaan bersih atau hasil penjualan tahunan.

Dari pengertian diatas dapat disimpulkan bahwa UMKM merupakan usaha ekonomi produktif yang dijalankan individu, rumah tangga, atau badan usaha ukuran kecil dimana penggolongan kriteria didasarkan pada batasan omzet pendapatan per tahun

\section{Kriteria Usaha Mikro, Kecil dan Menengah (UMKM)}

Menurut (Undang-Undang Nomor 20 Tahun 2008) Tentang Usaha Mikro, Kecil, dan Menengah 
juga dijelaskan perbedaan kriteria UMKM dengan Usaha Besar sebagai berikut:

1. Usaha Mikro: aset maksimal Rp 50.000.000,00 (lima puluh juta rupiah) tidak termasuk tanah dan bangunan tempat usaha dan omzet maksimal Rp 300,000.000,00 (tiga ratus juta rupiah) per tahun.

2. Usaha Kecil: aset lebih dari Rp 50.000.000,00 (lima puluh juta rupiah) sampai dengan $\mathrm{Rp}$ 500.000.000,00 (lima ratus juta rupiah) tidak termasuk tanah dan bangunan tempat usaha dan omzet maksimal lebih dari Rp 300,000.000,00 (tiga ratus juta rupiah) sampai dengan $\mathrm{Rp}$ 2.500.000.000,00 (dua milyar lima ratus juta rupiah) per tahun.

3. Usaha Menengah: aset lebih dari Rp 500.000.000,00 (lima ratus juta rupiah) sampai

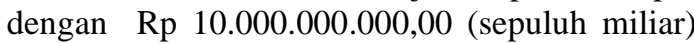
tidak termasuk tanah dan bangunan tempat usaha dan omzet lebih dari Rp 2.500.000.000,00 (dua milyar lima ratus juta rupiah) sampai dengan $\mathrm{Rp}$ 50.000.000.000,00 )lima puluh miliar) per tahun.

4. Usaha Besar: aset lebih dari $\mathrm{Rp} \mathrm{Rp}$ 10.000.000.000,00 (sepuluh miliar) tidak termasuk tanah dan bangunan tempat usaha dan omzet lebih dari Rp 50.000.000.000,00 (lima puluh miliar) per tahun

\section{Kekuatan dan Kelemahan Sektor UMKM}

Usaha Mikro, Kecil dan Menengah (UMKM) memiliki kekuatan potensial yang merupakan andalan yang menjadi basis pengembangan pada masa yang akan datang (Balitbang Buleleng, 2020) diantaranya yaitu:

1. Penyediaan lapangan kerja peran industri kecil dalam penyerapan tenaga kerja patut diperhitungkan, diperkirakan mampu menyerap sampai dengan $50 \%$ tenaga kerja yang tersedia.

2. Sumber wirausaha baru, keberadaan usaha kecil dan menengah selama ini terbukti dapat mendukung tumbuh kembangnya wirausaha baru.

3. Memiliki segmen usaha pasar yang unik, melaksanakan manajemen sederhana dan fleksibel terhadap perubahan pasar

4. Memanfaatkan sumber daya alam sekitar, industri kecil sebagian besar memanfaatkan limbah atau hasil dari industri besar atau industri yang lainnya

5. Memiliki potensi untuk berkembang dan mampu untuk mengembangkan sektor lain yang terkait di dalamnya.

Kelemahan yang sering juga menjadi faktor penghambat dan permasalahan dari UMKM terdiri dari 2 (dua) faktor yaitu:

1. Faktor internal, merupakan masalah klasik dari UMKM diantaranya:

a. Masih terbatasnya kemampuan sumber daya manusia b. Kendala pemasaran produk sebagian besar pengusaha Industri Kecil lebih memprioritaskan pada aspek produksi sedangkan fungsi-fungsi pemasaran kurang mampu dalam mengakseskannya, khususnya dalam informasi pasar dan jaringan pasar, sehingga sebagian besar hanya berfungsi sebagai tukang saja.

c. Kecendrungan konsumen yang belum mempercayai mutu produk Industri Kecil

d. Kendala permodalan usaha sebagian besar Industri Kecil memanfaatkan modal sendiri dalam jumlah yang relatif kecil

2. Faktor eksternal merupakan masalah yang timbul dari pihak pengembang dan pembina UMKM. Misalnya pemecahan solusi yang diberikan tidak tepat sasaran tidak adanya monitoring dan program yang tumpang tindih

\section{Program Pemulihan Ekonomi Nasional (PEN)}

Untuk menanggulangi dampak pandemi Covid-19, program Pemulihan Ekonomi Nasional (PEN) tertuang dalam Perpu 1/2020 dan turunan kebijakan fiskalnya diatur dalam (Peraturan Pemerintah (PP) No.23/2020.) Program Pemulihan Ekonomi Nasional (PEN) adalah rangkaian kegiatan yang disusun untuk pemulihan perekonomian nasional yang menjadi bagian dari kebijakan keuangan negara yang dilaksanakan oleh Pemerintah untuk percepatan penanganan pandemi covid-19 atau menghadapi situasi ancaman yang membahayakan perekonomian nasional atau stabilitas sistem keuangan serta penyelamatan ekonomi nasional. Program PEN memiliki tujuan untuk memberikan perlindungan, mempertahankan dan meningkatkan kemampuan ekonomi para Pelaku Usaha dalam menjalankan usahanya.

Sedangkan prinsip pelaksanaan program PEN menurut Peraturan Pemerintah (PP) No.23/2020 yaitu:

1. Asas keadilan sosial

2. Sebesar-besarnya untuk kemakmuran rakyat

3. Mendukung pelaku usaha

4. Menerapkan kaidah-kaidah kebijakan yang penuh kehati-hatian, serta-tata kelola yang baik, transparan, akseleratif, adil, dan akuntabel sesuai dengan ketentuan peraturan perundang-undangan;

5. Tidak menimbulkan moral hazard; dan

6. Adanya pembagian biaya dan risiko antar pemangku kepentingan sesuai tugas dan kewenangan masing-masing. 


\section{METODE PENELITIAN}

Metode penelitian yang digunakan pada penelitian ini adalah teknik analisis deskriptif kualitatif yaitu suatu penelitian yang bermaksud memahami fenomena tentang apa yang dialami oleh subjek penelitian misalnya perilaku, persepsi, motivasi, tindakan, dan lain-lain secara holistic menyeluruh dan dengan cara mendeskripsikan dalam bentuk kata-kata dan bahasa pada suatu konteks khusus yang alamiah serta dengan memanfaatkan berbagai metode alamiah. Teknik pengumpulan data menggunakan pendekatan studi literatur. Literatur yang digunakan untuk acuan penelitian meliputi artikel media massa, buku teks, dan penelusuran literatur online yang berkaitan dengan penelitian ini.

\section{HASIL DAN PEMBAHASAN}

\section{A. Desain Pemulihan Ekonomi Nasional}

Pemerintah telah menyiapkan desain pemulihan ekonomi nasional pada tahun 2020. Melalui desain inii akan menjadi pedoman Program Pemulihan Ekonomi Nasional (PEN). Hal ini dilakukan sebagai upaya memperkuat perekonomian. Pemerintah juga memberikan dukungan stimulus untuk usaha mikro, kecil dan menengah (UMKM) dan ultra mikro (UMi), hingga industri dan badan usaha milik negara (BUMN). Desain Program Pemulihan Ekonomi Nasional (PEN) dapat dilihat pada tabel berikut ini:

Tabel 1. Desain Pemulihan Ekonomi Nasional

\begin{tabular}{|c|c|c|c|c|}
\hline \multicolumn{3}{|c|}{ Q2 } & Q3 & Q4 \\
\hline \multirow{3}{*}{$\begin{array}{l}\text { Skenario } \\
\text { Dampak } \\
\text { Ekonomi }\end{array}$} & $\begin{array}{l}\text { Baseline } \\
\text { Dampak } \\
\text { Produksi }\end{array}$ & $\begin{array}{ll}\text { - } & \text { Pariwisata Terhenti (Transportasi, Akomodasi, Re } \\
\text { - } & \text { Perdagangan Turun Tajam } \\
\text { - } & \text { Manufaktur Terganggu }\end{array}$ & storan) & $\begin{array}{l}\text { - Aktivitas parivisata mulai hidup } \\
\text { Kembali } \\
\text { - Perdagangan meningkat } \\
\text { - } \quad \text { Manufaktur Kembali beraktivitas }\end{array}$ \\
\hline & \multirow{2}{*}{$\begin{array}{l}\text { Baseline } \\
\text { Dampak } \\
\text { Konsumsi }\end{array}$} & $\begin{array}{l}\text { - PSBB menurunkan konsumsi masyarakat } \\
\text { secara signifikan, baik formal maupun informal }\end{array}$ & \multicolumn{2}{|c|}{$\begin{array}{l}\text { Aktivitas konsumsi berangsur meningkat (elektronik, pakaian, } \\
\text { restoran, hotel, pariwisata, transportasi, dll.) }\end{array}$} \\
\hline & & \multicolumn{2}{|c|}{ - Kemiskinan dan pengangguran meningkat tajam (terutama informal) } & Pengangguran dan kemiskinan menurun \\
\hline \multirow{3}{*}{$\begin{array}{l}\text { Desain } \\
\text { Respon } \\
\text { Kebijakan }\end{array}$} & $\begin{array}{l}\text { Stimulus } \\
\text { Konsumen }\end{array}$ & $\begin{array}{l}\text { Percepatan dan penguatan subsidi dan bansos untuk } \\
\text { masyarakat miskin dana rentan miskin (tambahan sembako, } \\
\text { Kartu Prakerja, pembebasan tarif listrik, penambahan } \\
\text { penyaluran PKH) }\end{array}$ & \multicolumn{2}{|c|}{$\begin{array}{l}\text { Stimulus perluasan konsumsi dengan fokus kelas } \\
\text { menengah (pariwisata, restoran, transportasi, dll.) }\end{array}$} \\
\hline & \multirow{2}{*}{ Stimulus Usaha } & $\begin{array}{l}\text { Ultra Mikro dan UMKM } \\
\text { - } \quad \text { Penundaan pokok dan bunga UMKM dan UMi } \\
\text { - } \quad \text { Subsidi bunga kredit UMKM dan UMi } \\
\text { - } \quad \text { Insentif perpajakan untuk UMKM } \\
\text { - } \quad \text { Penjaminan kredit modal kerja untuk UMKM } \\
\text { - } \quad \text { Dana Insentif Daerah (DID) }\end{array}$ & & \multirow{2}{*}{$\begin{array}{ll}\text { Jumpstart sektor usaha } \\
\text { - } & \text { Penjaminan kredit modal } \\
& \text { kerja UMKM } \\
\text { - } & \text { Penyaluran kredit modal kerja } \\
& \text { BUMN } \\
\text { - } & \text { Penempatan dana di } \\
& \text { perbankan yang terdampak } \\
\text { restrukturisasi kredit } \\
\text { - } \quad \text { Investasi pemerintah (PMN) } \\
\text { ke BUMN } \\
\text { - Dana Insentif Daerah (DID) } \\
\text { - } \text { Dana dukungan untuk B30 }\end{array}$} \\
\hline & & $\begin{array}{l}\text { Industri dan BUMN } \\
\text { - Insentif perpajakan untuk industri } \\
\text { - } \quad \text { Dana talangan ke BUMN } \\
\text { - Penyaluran kredit modal kerja BUMN } \\
\text { - Penempatan dana di perbankan terdampak } \\
\quad \text { restrukturisasi kredit } \\
\text { - } \quad \text { Dana dukungan untuk B30 }\end{array}$ & & \\
\hline
\end{tabular}

Sumber: Bappenas (2020)

Berdasarkan tabel diatas dapat dilihat bahwa stimulus usaha yang dilakukan oleh pemerintah pada sektor usaha mikro, kecil dan menengah (UMKM) dan ultra mikro (UMi) meliputi penundaan pokok dan bunga UMKM dan UMi, subsidi bunga kredit dan UMi, insentif perpajakan untuk UMKM, penjaminan kredit modal kerja untuk UMKM dan Dana Insentif Daerah (DID). Hal ini dilakukan untuk membagkitkan kembali geliat usaha pada sektor UMKM yang memiliki kontribusi cukup besar terhadap pemulihan perekonomian pada masa pandemi saat ini. Desain Program Pemulihan Ekonomi Nasional (PEN) menjadi strategi kebijakan percepatan pemulihan perekenomian sebagai mitigasi dampak pandemi.

\section{B. Kebijakan Penanganan Pandemi Sektor UMKM}

Stimulus terkait kebijakan eksisiting penanganan pandemi sektor UMKM dapat dilihat pada tabel berikut ini: 
Tabel 2. Stimulus Kebijakan Penanganan Pandemi Sektor UMKM

\begin{tabular}{|c|c|}
\hline Kebijakan & Keterangan \\
\hline $\begin{array}{l}\text { Penundaan Angsuran } \\
\text { Pokok dan Bunga } \\
\text { UMKM UMi }\end{array}$ & $\begin{array}{l}\text { - Penundaan cicilan pokok selama } 6 \text { bulan } \\
\text { - Pembebasan bunga cicilan selama } 3 \text { bulan dan diskon 50\% selama } 3 \text { bulan untuk } \\
\text { nasabah KUR }\end{array}$ \\
\hline $\begin{array}{l}\text { Subsidi Bunga Kredit } \\
\text { UMKM dan Umi }\end{array}$ & $\begin{array}{l}\text { - Kredit UMK sebesar 6\% selama } 3 \text { bulan pertama, } 3 \% \text { selama } 3 \text { bulan kedua } \\
\text { - Kredit Usaha Menengah sebesar 3\% selama } 3 \text { bulan pertama, 2\% selama } 3 \text { bulan } \\
\text { kedua. }\end{array}$ \\
\hline $\begin{array}{l}\text { Insentif Perpajakan } \\
\text { Bagi UMKM }\end{array}$ & $\begin{array}{l}\text { - Pembebasan/Penanggungan Tarif pajak 0,5\% dalam PP 23/2018 } \\
\text { - Insentif PPh Pasal } 21 \\
\text { - Insentif pembebasan PPh Pasal } 22 \\
\text { - Pengurangan 30\% angsuran PPh Pasal } 25 \\
\text { - Insentif restitusi Pajak Pertambahan Nilai (PPN) dipercepat hingga jumlah lebih } \\
\text { bayar maksimal Rp5 miliar }\end{array}$ \\
\hline Dana Insentif Daerah & $\begin{array}{l}\text { - Stimulus untuk pemulihan ekonomi di daerah yang juga ditujukan untuk UMKM } \\
\text { terdampak. } \\
\text { - Dana Insentif Daerah bersumber dari cadangan bagian anggaran bendahara umum } \\
\text { negara (BA BUN) }\end{array}$ \\
\hline $\begin{array}{l}\text { Stimulus Modal } \\
\text { Kerja: Modal Kerja } \\
\text { Darurat Khusus Bagi } \\
\text { UMKM Terdampak } \\
\text { Covid-19 }\end{array}$ & $\begin{array}{l}\text { - Stimulus bantuan modal kerja kepada UMKM yang belum pernah mendapatkan } \\
\text { pembiayaan baik dari lembaga keuangan maupun sistem perbankan. } \\
\text { - Estimasi untuk kebutuhan modal kerja UMKM dilihat dari outstanding kredit dan } \\
\text { jumlah UMKM yang membutuhkan, sisi profil risiko kredit UMKM. } \\
\text { - Penjamin adalah PT Jamkrindo dan PT Askrindo } \\
\end{array}$ \\
\hline $\begin{array}{l}\text { Penyertaan ke Bank } \\
\text { Himbara }\end{array}$ & $\begin{array}{l}\text { - Bernilai total Rp } 30 \text { Triliun untuk empat bank Himbara } \\
\text { - Diarahkan untuk fokus ke UMKM } \\
\text { - Bunga ditetapkan } 80 \% \text { dari } 7 \text { Day BI Repo Rate } \\
\end{array}$ \\
\hline Banpres Produktif & $\begin{array}{l}\text { - Banpres produktif merupakan bantuan tunai dari pemerintah untuk usaha mikro } \\
\text { dan kecil. } \\
\text { - Dianggarkan sebesar Rp } 28,8 \text { Triliun } \\
\text { - Calon penerima ditargetakan mencapai } 12 \text { juta UMK }\end{array}$ \\
\hline
\end{tabular}

Sumber: Bappenas (2020)

Berdasarkan tabel diatas dapat dilihat bahwa stimulus kebijakan penanganan pandemi sektor UMKM dalam hal ini pemerintah memeprioritaskan pemulihan ekonomi negara. Berdasarkan data dari Kementrian Keuangan dari total biaya yang dialokasikan pemerintah untuk penanganan Covid-19 pada tahun 2020, adalah sebesar Rp 695,2 triliun, sejumlah Rp 123,46 triliun dialokasikan khusus untuk mendukung UMKM.

Jumlah dana yang dialokasikan tersebut untuk lima kegiatan, yakni subsidi bunga sebesar Rp 35,28 triliun; penempatan dana untuk restrukturisasi sebesar $\mathrm{Rp} 78,78$ triliun; belanja imbal jasa penjaminan (IJP) sebesar Rp 5 triliun; sedangkan untuk PPh final UMKM ditanggung pemerintah (DTP) sebesar Rp 2,4 triliun; serta pembiayaan investasi kepada koperasi melalui Lembaga Pengelola Dana Bergulir Koperasi,
Usaha Mikro, Kecil, dan Menengah (LPDB KUMKM) sebesar Rp 1 triliun rupiah.

Alokasi dana tersebut menempati urutan kedua dari sisi jumlah dari total lima alokasi biaya penanganan Covid-19 yang lain, yakni untuk perlindungan sosial sebesar Rp 203,9 triliun, insentif usaha sebesar Rp 120,61 triliun, sektoral kementerian/lembaga dan pemda sebesar Rp 106,11 triliun, untuk kesehatan sebesar Rp 87,55 triliun, serta pembiayaan korporasi sebesar Rp 53,57 triliun. Hal ini dilakukan demi menyelamatkan ekonomi negara dengan mendukung pemulihan UMKM sebagai perioritas pertama.

\section{Realisasi Program Pemulihan Ekonomi Nasional Sektor UMKM}

Untuk percepatan penyaluran dan 
memperluas sasaran pada UMKM pemerintah terus berupaya untuk segera menyalurkan bantuan program Pemulihan Ekonomi Nasional (PEN). Realisasi penyaluran sejumlah program PEN terhadap sektor UMKM sampai dengan bulan Desember 2020 sudah mencapai Rp 440,03 triliun. Angka ini setara dengan 63,1 persen dari total pagu yang mencapai Rp 695,2 triliun. Penyerapan anggaran berangsur naik setelah sebelumnya pada bulan November 2020, baru mencapai Rp 366,86 triliun atau 52,8 persen. . Realisasi sampai bulan November 2020 dapat dilihat pada gambar berikut ini:

\section{Realisasi Anggaran Penanganan Covid-19 dan Pemulihan Ekonomi Nasional (per 2 November 2020)}

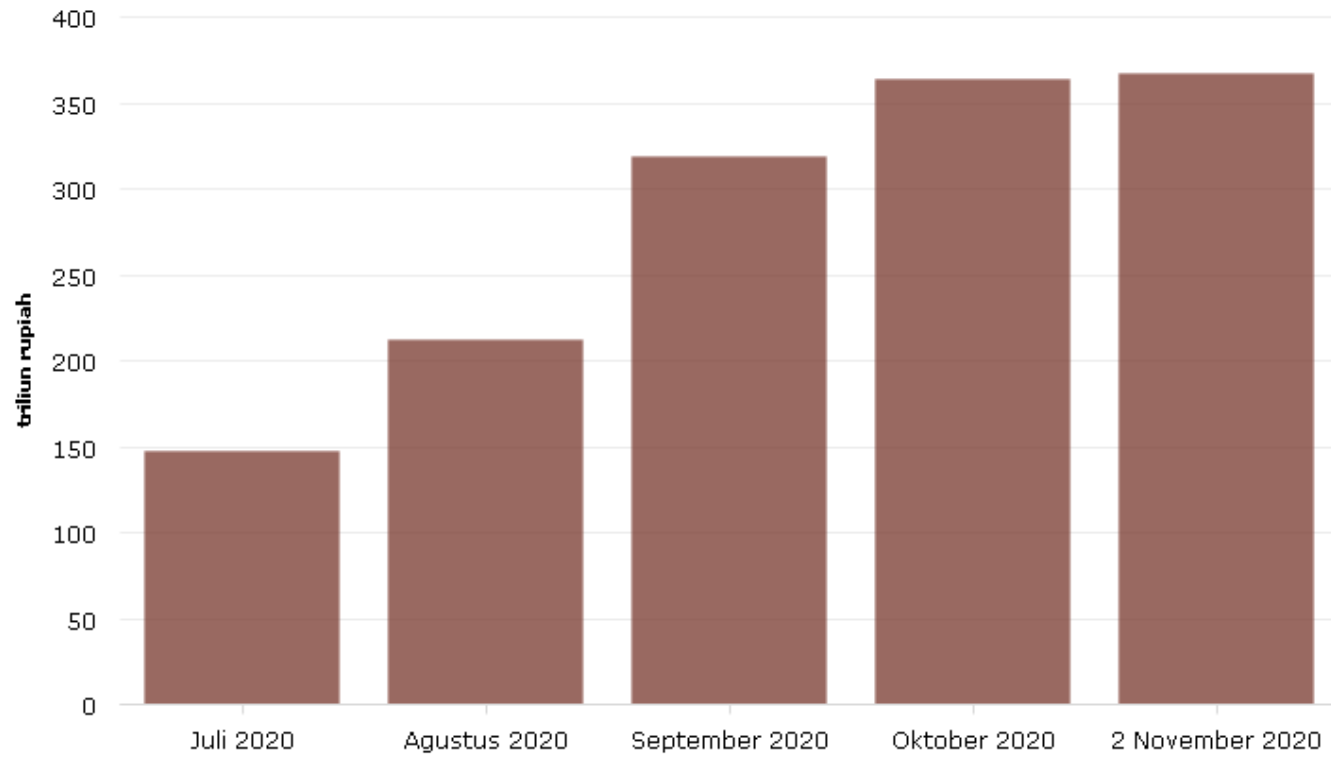

Sumber: Satuan Tugas Pemulihan dan Transformasi Nasional dalam (Katadata, 2020)

Gambar 3.

Realisasi Anggaran Pemulihan Ekonomi Nasional

Melalui Program PEN salah satu sektor dengan penyerapan angka tertinggi adalah usaha mikro kecil menengah (UMKM). Lewat Program Bantuan Presiden (BanPres) Produktif Usaha Mikro realisasi mencapai sebesar Rp 26,48 triliun dari pagu anggaran sebesar 28,82 triliun, atau 91,94 persen. Bantuan tersebut berupa dana hibah sebesar Rp 2,4 juta bagi setiap pelaku usaha mikro kecil memberikan kontribusi besar penyerapan secara keseluruhan pada enam program di klaster UMKM, yaitu sebanyak Rp 101,07 Trilun, atau $87,26 \%$ dari pagu anggaran $\mathrm{Rp}$ 115,83 Triliun

Sedangkan Program Banpres Produktif Usaha Mikro sudah disalurkan ke 11 juta pelaku usaha dalam 27 tahap. Target sasaran bantuan ini mencapai 12 juta pelaku usaha sampai tahun 2020 berakhir. Bedasarkan data dari Kementerian Koperasi dan UMKM, tiga daerah tercatat sebagai penerima terbanyak Banpres ini, yakni Jawa Barat sebanyak 1.223.010 pelaku usaha mikro, Jawa Timur sebanyak 1.534.287 usaha mikro, dan Jawa Tengah sebanyak 1.530.021 usaha mikro.
Melihat manfaat dari program ini cukup besar, pemerintah melalui Komite Penanggulangan COVID-19 dan Pemulihan Ekonomi Nasional (KPCPEN), bersama dengan Kementerian Koperasi dan UKM, akan terus mendorong realisasi penyerapan anggaran program ini. pemerintah berencana meneruskan program ini dan dapat diperluas cakupannya pada tahun berikutnya, sehingga mampu mempercepat pemulihan perekonomian nasional.

\section{KESIMPULAN}

Berdasarkan hasil pembahasan dapat disimpulkan bahwa Program Pemulihan Ekonomi Nasional (PEN) memiliki dampak positif bagi sektor UMKM pada masa pandemi covid-19 sebagai langkah kebijakan yang diambil oleh pemerintah untuk mendukung pemulihan perekonomian nasional khususnya sektor UMKM yang memiliki kontribusi cukup besar. Stimulus kebijakan penanganan pandemi sektor UMKM yang meliputi penundaan pokok dan bunga UMKM dan UMi, subsidi bunga 
kredit dan UMi, insentif perpajakan untuk UMKM, penjaminan kredit modal kerja untuk UMKM, Dana Insentif Daerah (DID), penyertaan bank dan banpres produktif menjadi strategi penyelematan pelaku usaha UMKM untuk mampu bertahan pada masa pandemi dan meningkatkan produktivitas serta kinerja UMKM. Realisasi penyerapan Program PEN yang memiliki manfaat cukup besar menjadi acuan pemerintah berencana untuk meneruskan program ini. Rekomendasi kebijkan penguatan UMKM tidak hanya pada masa pandemi tetapi juga pada masa pemulihan dan pasca pandemi sehingga percepatan pemulihan ekonomi nasional dapat mencapai kestabilannya.

\section{REFERENSI}

Undang-Undang No. 20. (2008). Usaha Mikro, Kecil dan Menengah (UMKM).

Balitbang, Buleleng. (2020). Kajian Dampak Pandemi Covid 19 Terhadap UMKM Di Kabupaten Buleleng. Retrieved July 11, 2021, from

https://balitbang.bulelengkab.go.id/upload/kon ten/69-kajian-dampak-pandemi-covid-19terhadap-umkm-di-buleleng.pdf

Bappenas. (2020). Kajian Kebijakan Penanggulangan Dampak COVID-19 terhadap UMKM Survei Kebutuhan Pemulihan Usaha Bagi UMKM Indonesia. Retrieved from https://aptika.kominfo.go.id/wpcontent/uploads/2020/12/BAPPENASPenanggulangan-Dampak-Covid-19-terhadapUMKM-Final-v1_0.pdf
Faqir, A. Al. (2021). Program PEN Bantu Bangkitkan Geliat UMKM Selama Masa Pandemi. Retrieved July 10, 2021, from https://www.merdeka.com/uang/program-penbantu-bangkitkan-geliat-umkm-selama-masapandemi.html

Hamidah, Q. R., Sejati, A. T. P., \& Mujahidah, A. Z. (2019). The Development of Small and Medium Businesses (MSMEs) Based on Tecnology to Deal with The Industrial Revolution 4.0. Social, Humanities, and Educational Studies (SHEs): Conference Series, 2, No. 1, 345-349. https://doi.org/https://doi.org/10.20961/shes.v2 i1.38431

Peraturan Pmerintah, 2020, No. 23 (n.d.). Program Pemulihan Ekonomi Nasional (PEN). Retrieved July 10, 2021 from https://www.kemenkeu.go.id/media/15124/faq -pp-no-23-2020.pdf

Putri, A. S. (2019). Peran UMKM dalam Perekonomian Indonesia. Retrieved July 10, 2021, from https://www.kompas.com/skola/read/2019/12/ 20/120000469/peran-umkm-dalamperekonomian-indonesia?page=all.

Saputra, D. (2021). Survei BI : 87,5 Persen UMKM Indonesia Terdampak Pandemi Covid-19. Retrieved July 10, 2021, from https://ekonomi.bisnis.com/read/20210319/9/1 370022/survei-bi-875-persen-umkmindonesia-terdampak-pandemi-covid-19

Yoshio, Alfons, Katadata (2020) Realisasi Program PEN Capai Rp 440 Triliun, Bantu UMKM Bertahan. Retrived July 11, 2021, from https://katadata.co.id/ariemega/berita/5fd46595 013bd/realisasi-program-pen-capai-rp-440triliun-bantu-umkm-bertahan 